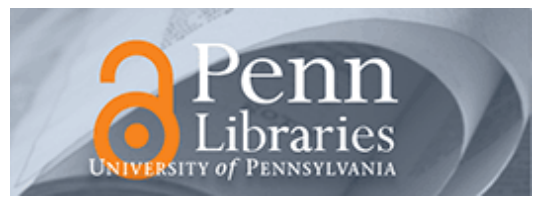

University of Pennsylvania

ScholarlyCommons

Management Papers

Wharton Faculty Research

6-2001

\title{
Internal Capabilities, External Networks, and Performance: A Study on Technology-Based Ventures
}

Choonwoo Lee

Kyungmook Lee

Johannes M. Pennings

University of Pennsylvania

Follow this and additional works at: https://repository.upenn.edu/mgmt_papers

Part of the Business Administration, Management, and Operations Commons, and the Entrepreneurial and Small Business Operations Commons

\section{Recommended Citation}

Lee, C., Lee, K., \& Pennings, J. M. (2001). Internal Capabilities, External Networks, and Performance: A Study on Technology-Based Ventures. Strategic Management Journal, 22 (6-7), 615-640. http://dx.doi.org/ 10.1002/smj.181

This paper is posted at ScholarlyCommons. https://repository.upenn.edu/mgmt_papers/43

For more information, please contact repository@pobox.upenn.edu. 


\title{
Internal Capabilities, External Networks, and Performance: A Study on Technology-Based Ventures
}

\author{
Abstract \\ This study examined the influence of internal capabilities and external networks on firm performance by \\ using data from 137 Korean technological start-up companies. Internal capabilities were operationalized \\ by entrepreneurial orientation, technological capabilities, and financial resources invested during the \\ development period. External networks were captured by partnership- and sponsorship-based linkages. \\ Partnership-based linkages were measured by strategic alliances with other enterprises and venture \\ capitalists, collaboration with universities or research institutes, and participation in venture associations. \\ Sponsorship-based linkages consisted of financial and nonfinancial support from commercial banks and \\ the Korean government. Sales growth indicated the start-up's performance. Regression results showed \\ that the three indicators of internal capabilities are important predictors of a start-up's performance. \\ Among external networks, only the linkages to venture capital companies predicted the start-up's \\ performance. Several interaction terms between internal capabilities and partnership-based linkages have \\ a statistically significant influence on performance. Sponsorship-based linkages do not have individual \\ effects on performance but linkage with financial institutions has a multiplicative effect with \\ technological capabilities and financial resources invested on a start-up's performance. Implications and \\ directions for future research were discussed.

\section{Keywords} \\ entrepreneurship, capabilities, social capital, social networks, start-up companies, innovation

\section{Disciplines} \\ Business Administration, Management, and Operations | Entrepreneurial and Small Business Operations
}




\title{
Internal Capabilities, External Linkages, and Performance: A Study on Technology-based Korean Ventures
}

\section{draft 13}

\author{
Choonwoo Lee \\ College of Business Administration \\ Seoul National University \\ Tel.: +82-(2)-880-6939 \\ Fax: +82-(2)-878-3154 \\ e-mail: choonwoo@plaza1.snu.ac.kr
}

\author{
Kyungmook Lee \\ College of Business Administration \\ Seoul National University \\ Tel.: +82-(2)-880-6926 \\ Fax: +82-(2)-878-3154 \\ e-mail: kmlee@snu.ac.kr \\ Johannes M. Pennings* \\ Department of Management \\ The Wharton School \\ University of Pennsylvania \\ 2000 Steinberg Hall-Dietrich Hall \\ Tel:215 898-7755 \\ Fax:215 898-0401 \\ e-mail: pennings@wharton.upenn.edu
}

*Corresponding author 


\begin{abstract}
This study examined the influence of internal capabilities and organizational linkages to external entities on firm performance by using data from 143 Korean business ventures. Internal capabilities were operationalized by entrepreneurial orientation, technological capabilities and financial resources invested. External linkages were captured by partnership-based linkages and sponsorship-based ones. Partnership-based linkages were measured by strategic alliance with other firms including venture capitalists, participation in venture associations, and collaboration with universities or research institutes. Sponsorship-based linkages consisted of financial and non-financial support from commercial banks and the Korean government. The competitiveness of products/services indicated organizational performance. Regression results showed that technological capabilities and financial resources are important predictors of organizational performance. Among external linkages, alliance with other firms and venture capital companies significantly enhances organizational performance. Several interaction terms have very significant influence on performance. Implications and directions for future research were discussed.
\end{abstract}




\section{INTRODUCTION}

The rise of the internet and the explosive growth of computer hardware and software development has overtaken the phenomenal growth of biotechnology. Yet in all these sectors, and across the globe from the Pacific Rim, the US and EU, particularly, we have witnessed major waves of wealth creation. The agents "behind" this wealth creation have been individuals and classes of individuals who practiced the art of "creative destruction" (Schumpeter, 1934).

Schumpeter (1934) has informed us about new business ventures and their entrepreneurs as the prime movers in modern economic development. They create new jobs (Birley, 1986) and foster technological innovations of industries (Tushman and Anderson, 1986). However, such nascent firms face what Stinchcombe (1965) calls “a liability of newness.” As a result, entrepreneurship and strategic management scholars, policy-makers, and entrepreneurs alike are very concerned with factors that contribute to wealth creation process of new business ventures. Despite of the deep interest and theoretical importance of the wealth creation process, previous studies have explored the process without scrutinizing its entrepreneurial underpinnings. For example, we do not have comprehensive insights about the key success factors of new ventures in high technology environments such as the internet and biotechnology. In this paper we attempt to uncover these success factors. Applying the resource-based view of the firm and social capital theory, this paper examines firm internal capabilities and its linkages with significant entities in the external environment. We then test some hypotheses about their integral impact on the performance of new ventures.

What determines organizational performance is a perennial research question for organizational scholars. Numerous perspectives have been developed to explain performance differentials. Some perspectives have an external slant, most notably industrial organization (e.g., Caves, 1984) and population ecology (Hannan and Freeman, 1985), and de-emphasized a concern for within-industry variations in performance. By contrast, other 
perspectives have a strong focus on organizational conditions and have explored the factors that drive performance differences. This paper invokes firm-level theories to account for the variation in wealth creation among entrepreneurial firms. Obviously, new ventures, still in the stage of adolescence (Brüderl, Preisendörfer, and Ziegler, 1992) have not yet experienced the initial selection process through which substandard firms are cleared by the market. Let us review the two theories that are central to this inquiry.

First, the resource-based view of the firm (hereafter RBV) emphasizes firm idiosyncratic resources (e.g., Barney, 1991; Penrose, 1959; Wernerfelt, 1984), especially resources that reside within organizations. RBV regards the firm as a bundle of resources and suggests that their attributes significantly affect the firm's competitive advantage; and by implication performance. (Barney, 1986, 1991; Penrose, 1959; Peteraf, 1993; Wernerfelt, 1984). Most conspicuous among these resources are those that are valuable, scarce, imperfectly tradable, and hard to imitate (Barney, 1986; Dierickx and Cool, 1989; Peteraf, 1993; Reed and DeFllippi, 1990). The most prominently investigated classes include human, technological, financial resources, organizational culture, and managerial capabilities (Barney, 1986; Hall, 1991, 1993; Prahalad and Hamel, 1990).

Second, social capital theory suggests that a firm's external networks form a major contributor to its performance (Leenders and Gabbay, 1999). Organizations transact with suppliers and other partners in order to acquire external resources to produce products/services at competitive prices, adjusted for quality such that they can attract and retain customers (Burt, 1992; Pennings and Lee, 1999; Pennings, Lee, and Witteloostuijn, 1998; Uzzi, 1995). Their ability to mobilize extramural resources and attract customers is conditional on external networks since social relations mediate economic transactions and confer organizational legitimacy (Granovetter, 1985).

As implied these two perspectives have divergent concerns with the roots of competitive advantage, with RBV stressing the internally accumulated resources or capabilities while social capital theory has underscored its relational characteristics with external entities. The two theories ought to be synthesized, since business ventures should 
develop firm specific assets while obtaining critical other resources through their social networks. Drawing on the two perspectives, this paper combines the joint influence of internal capabilities and external contacts on the performance of technology-based Korean business start-ups. We collected survey data from 143 business ventures involved in computer software, electric and electronic, and biotechnological products.

This study does not only push the envelope of theory and research of creative destruction by high-tech start-ups. It is also important for the practice of entrepreneurship itself. The current body of knowledge on technology-based young firms is still in its infancy. Theoretically, this study can further test empirical validity of RVB and social capital theory on competitive advantage — a validity that still awaits further scrutiny as much of the pertinent literature is largely conceptual. The work on social capital has been enriched by an impressive program of empirical data collection but awaits further theoretical fine tuning, nor have we encountered many efforts in which the two lenses on start-ups have been combined. Practically speaking, this study provides managerial implications to entrepreneurs in technology-based industries. For example we make suggestions regarding the kinds of internal capabilities or external contacts that are critical to the success of their ventures.

\section{THEORY AND HYPOTHESES}

\section{Internal Capabilities and Organizational Performance}

The RBV literature suggests that idiosyncratic internal resources define a durable competitive advantage. Which resources stand out in shaping performance of technology-based business ventures? Entrepreneurs as catalysts of spells of new venture activity have been scrutinized over the past decades. Their success producing qualities include personality attributes such as entrepreneurial spirit and attitude, general human capital, industry and firm specific experiences and learning from previous start-up experience (e.g., Cooper and Bruno, 1977; Kazanjian, 1988; Miller, 1983; Mintzberg and 
Waters, 1987; Van de Ven, Hudson, and Schroder, 1984). The founder's attributes are among the most central resources of business ventures (Dollinger, 1995; Chandler and Hanks, 1994).

Notwithstanding the important role of the founder, several papers (e.g., Eisenhardt and Bourgeois, 1988; Eisenhardt and Schoonhoven. 1990; Goodstein and O’Reilly, 1988; Roure and Maidique, 1986) have emphasized the attributes of her top management team (founding team) such as size, level of joint work experience and member heterogeneity in functional backgrounds. Still other work on a technology-based venture's success and failure has sought to cover characteristics of venture as a whole. They include founding strategy (Romanelli, 1989), technical innovation within the core technology (Boeker, 1989; Maidique and Patch, 1982), and level of capital infusion after its founding (Schoonhoven et al., 1990). This paper examines some attributes of the start-up as a whole while controlling for founder's attributes.

The RVB-inspired entrepreneurship literature combined with exploratory interviews with top executives of our sample firms suggests three important internal capabilities that significantly influence start-up performance. They include entrepreneurial orientation, technological capabilities, and financial resources.

Entrepreneurial orientation. Entrepreneurs usually create and run their venture to develop a market niche with new products/services or to substitute established players with better quality, cheaper price, etc. These processes/activities are identified with the process of creative destruction (Schumpeter, 1934, 1947) and defined as entrepreneurship (Knight, 1921). To succeed, entrepreneurs should run the organization "entrepreneurially" (Covin and Slevin, 1991; Zahra, 1993). This term entrepreneurial orientation (EO hereafter) captures the organizational processes, methods, and styles used to implement the venture's founding (Lumpkin and Dess, 1996; Miller, 1983). EO has figured prominently in the literature on the explanation of start-up performance (e.g., Lumpkin and Dess, 1996). The RBV literature itself has not treated EO as a source of sustainable competitive advantage, even though it constitutes one of the most critical resources. Conceptually, we distinguished three dimensions of EO (innovativeness, risk-taking propensity, and 
proactiveness), as suggested by Miller (1983) and adopted or extended by several other studies (e.g., Covin and Slevin, 1989; Ginsberg, 1985; Lumpkin and Dess, 1996; Morris and Paul, 1987; Schafer, 1990).

Innovativeness reflects a firm's propensity to engage in new idea generation, experimentation, and $\mathrm{R} \& \mathrm{D}$ activities resulting in new products/services, market penetration, and manufacturing processes (Lumpkin and Dess, 1996). Creative destruction calls for entrepreneurs to suspend current paradigms and invest significant resources in new and untested activities (Schumpeter, 1934, 1947; Kao, 1995). Without innovation, young organizations would have to rely on traditional ways of doing business; traditional products/services, traditional distribution channels, and usually at a premium compared to incumbents. Head-to-head competition with established players is bound to result in failure due to resource shortcomings such as scale diseconomies and questionable reputation if not. As a result, new entrants should differentiate themselves from incumbents by introducing product, process or marketing innovations.

Firms with an entrepreneurial orientation typically display risk-taking behavior, illustrated by large resource commitments to seize new opportunities in the marketplace. Any innovation involves considerable uncertainty before it is ready to be commercialized (Nelson and Winter, 1982). The risk-taking propensity of a firm can be inferred from its willingness to incur large and risky resource commitments to uncertain and novel business (Brockhaus, 1982; Lumpkin and Dess, 1996; Miller, 1983; Miller and Friesen, 1978).

Finally, proactiveness refers to a firm's approach to market opportunities through active market research and first-mover actions such as introduction of new products/services ahead of competitors (Lumpkin and Dess, 1996; Miller and Friesen, 1978). Proactivenss is crucial since it entails a forward-looking perspective that is accompanied by innovative or new-venturing activity. Being a pioneer by anticipating and pursuing new opportunities and participating in emerging markets is a hallmark of entrepreneurship. Proactive business ventures tend to become first-movers by forging a new market segment or by substituting established markets with new products/services (Christensen, 1997). In fact incumbents have often a mindset, bolstered by incentives that 
blind sight them towards emergent markets. By exploiting asymmetries in the market place, proactive business ventures capture unusually high returns and get a head start in establishing brand recognition.

The discussion provides following hypothesis.

Hypothesis 1: The level of entrepreneurial orientation is positively associated with organizational performance.

Technological capabilities. In RBV, technological capabilities define the roots of a firm's sustainable competitive advantage. They are obviously even more central in high technology firms. They are among the most critical success factors shaping the performance of technology-based organizations in general (e.g., Bettis and Hitt, 1995; Henderson and Clark, 1990; Tushman and Anderson, 1986) and technology-based start-ups in particular (Chandler and Hanks, 1994; Dollinger, 1995; Shrader and Simon, 1997). They comprise technological knowledge, trade secrets, technical know-how generated by R \& D and other technology-specific intellectual capital (Dollinger, 1995). Patents and utility models patents and designs, in particular, stand out as capabilities that are unique, sticky, in short, “inappropriable” (Teece, 1995). These intellectual property protected by patent laws confer exclusive rents by allowing new ventures to solely commercialize the toils of their new product development efforts, seize market opportunities, and differentiate themselves from incumbents.

Not all capabilities can be shielded by patent laws, most notable those that defy codification. Technological capabilities not protected by patent laws are vulnerable to imitation and replication by competitors, especially large established competitors. Further appropriability can be inflicted on start-ups by scouting key technicians and researchers with a lure of thick compensation that new ventures cannot match, especially when those capabilities are embodied in technicians and researchers. However, skills that are complex and tacit are hard to copy because they remain largely embedded in the routines and practices of the firm (Kogut and Zander, 1995; Winter, 1994). Therefore, tacit capabilities 
enjoy an attractive appropriability regime (Teece, 1995). Among tacit skills is a firm’s quality control capability. Since quality control requires also complex organizational arrangements, it constitutes a major competitive advantage for new business ventures that cannot be readily alienated.

New products in general and those from new ventures in particular are shrouded by a good deal of causal ambiguity. Enhanced functionality or modified reliability of product quality enters the customer's awareness slowly. Potential customers face uncertainty when choosing to purchase from an incumbent versus a new entrant. A firm's reputation spills over into the evaluation of new products and services. Compared to start-ups, incumbents are endowed with goodwill and brand equity to offset a new product's quality concerns. Customers unsure about the quality benefits of innovations might, therefore, be even more skeptical if its producer is a new entrant, and still lacking legitimacy. Absent other product quality signals, acquiring and leveraging quality assurance from prestigious domestic and international partners might decrease a customer's uncertainty and bolster the performance of new ventures. This discussion leads us to following hypothesis.

Hypothesis 2: Technological capabilities having a positive appropriability regime are positively associated with a technological start-up’s performance.

Financial resources. During their formative years, start-ups invest much of their available financial capital in product and market development. However, they usually run short of financial resources for technology development, marketing research and advertising, because they lack liquid assets or credit lines as do their of more established peers. Since they typically have no history of transactions with financial institutes, and more over are seen as extremely risky, they incur premium when securing external resources from commercial banks, suppliers and other firms. Start-ups are charged higher interest rates by financial institutes, pay higher prices and with harsher credit terms for supplies and parts, and adopt above-market compensation plans for their employees. In short, during their early years, start-ups with inadequate financial resources face a critical 
disadvantage before they evolve into a full-fledged company (Dollinger, 1995; Schoonhoven et al., 1990; Shrader and Simon, 1997). Schoonhoven et al. (1990) argued that a new venture's initial capital expenditures increase the speed with which its first products reaches the market. Roberts and Hauptman (1987) provided evidence, showing that "under-financed" biomedical firms pursuing significant technological break-through, endured lower performance.

Young firms well endowed with capital enjoy many advantages. They can invest more in the development of products, advertising, marketing, and recruit valuable human capital. Other things being equal, start-up having invested more in $R \& D$, advertising, and market research during the development stage, are more likely to perform better in the future. This discussion suggests the following hypothesis.

Hypothesis 3: A venture's financial resources invested during the development period are positively associated with its performance.

\section{Linkages to External Entities and Organizational Performance}

Organizations, whether established ones or start-ups, cover only part of their value chain and depend critically on their environment (Pfeffer and Salancik, 1978). Firms have limited resources, outsource certain parts of the value chain, and transact with other economic actors having complementary assets. External contacts perform a very important role in the procurement of those assets, since economic actions are embedded within larger organizational networks. Networks provide opportunities for intelligence and external control (Burt, 1992), but also limit a firm's choices and actions transcending pure cost-benefit analysis (Granovetter, 1985). Networks are vital to the discovery of opportunities (Amabile, 1992), to the testing of ideas, and to garner resources for the formation of the new organization (Aldrich and Zimmer, 1986). Potential partners are often very reluctant to invest their reputation, capital, or other resources in a new business venture, since there exists considerable uncertainty about the embryonic venture's financial 
prospects, if not its longevity. "Embedded" (Uzzi, 1995) ties with partners enhance support for a new venture by the commitment of their resources. Uzzi (1995) defines embedded ties as those that are reinforced by mutual feelings of attachment, reciprocity, and trust. Contacts are conducive to the mobilization of external resources from third parties since those very contacts signal positive assessments regarding the start-up future prospects (Stuart, Hoang, and Hybels, 1999), Dollinger (1985) provided ample evidence that successful entrepreneurs were particularly active in networking with business people and regulators. Hansen (1995) likewise found that entrepreneurial networks are positively associated with organizational growth.

Organizational networks have been investigated as a key factor that influences organizational actions and performance. The term "corporate social capital” has recently come into vogue. Social capital captures the beneficial effect of social networks on organizational performance (e.g., Pennings et al., 1998). Corporate social capital can be defined as "the set of resources, tangible or virtual, that accrue to a corporate player through the player's social relationships, facilitating the attainment of goals (Gabbay and Leenders, 1999: 3)." Most prior studies investigated the concept, attributes and function of social capital, but have not articulated its nature in the context of start-ups and their value creation. In this paper, we make the important distinction between "partnership-based linkages" and "sponsorship-based linkages" in order to conceptualize the social capital of hi-technology ventures.

Partnership-based linkages are cooperative and bilateral relationships in which partners give-and-take resources for a considerable time span. Sponsorship-based linkages are unilateral relationships as the sponsor commits unilateral support to a business venture without receiving explicit rewards. Both kinds of linkages enable a (small) firm to acquire critical resources (Baum and Oliver, 1991; Eisenhardt and Schoonhoven, 1996).

Partnership-based linkages. Partnership-based linkages to external entities can be defined as cooperative or collaborative relationships with environmental constituents (Baum and Oliver, 1991; Dollinger, 1989). Literature review and interviews with top executives of our sample firms suggest that four kinds of partnership-based linkages are 
crucial to enhance the performance of technology-based young organizations. They are linkages to (1) other technology-based business ventures, (2) resource supplying organizations including venture capitalists, (3) universities and research institutes, and (4) venture associations and informal entrepreneurs' network.

Strategic alliance is used as an instrument to have a long-term relationship with suppliers and customers. Strategic alliances with suppliers and customers provide a great advantage to young firms. Strategic alliance can signal enhanced legitimacy for firms (Baum and Oliver, 1991; Eisenhardt and Schoonhoven, 1996), provide opportunities for gaining new competence (Hagedoorn, 1993; Hennart, 1991), and offer specific knowledge-based resources such as manufacturing or customer information (Hamel et al., 1989; Teece, 1987). Alliance can also help firms to gain market power (Hagedoorn, 1993), move more quickly into new markets and technologies, and create options for future investment (Eisenhardt and Schoonhoven, 1996). Through strategic alliances, new ventures can secure stable sources of resource supplies and sales of products/services. New ventures usually have a great difficulty in securing suppliers and customers who are questioning the long-term survival of the venture. Suppliers are reluctant to transact with a new venture especially when the transaction requires transaction-specific investments, because the investments are not likely to be recovered when the venture fails. Customers are also reluctant to buy products/services of new ventures, because customers suspect the quality and performance of products/services produced by new ventures, and worry about repair services and value of warranty in cases of the venture's failure. Several studies have illustrated the benefit of having strong relationship with others for a venture success. For instance, Uzzi (1996) showed that strong ties with suppliers, which are very similar to strategic alliance, enhance the survival chance of new ventures. Stuart, Hoang, and Hybels (1999) also reported that biotechnology firms allied with prominent partners go to initial public offering (IPO) faster and earn greater valuation at IPO than firms lacking such connections.

Equity investment of venture capitalists into a new venture not only provides financial resources and management know-how to the venture but also enhances its 
legitimacy. Since venture capital companies that invested in a new venture have a strong incentive to make the venture succeed, they provide management related know-how and refer potent professionals who can help the venture. Potential suppliers, buyers, investors and employees face a great deal of uncertainty in deciding whether they transact with the new venture or not. The equity participation of venture capitalists signals to those suspecting entities that the new venture has a high chance of success. The legitimacy and lowered perceived uncertainty enable a new venture to mobilize external resources with better terms (Podolny, 1993; Stuart, Hoang, and Hybels, 1999).

The collaboration with universities and research institutes provides a means of developing technological knowledge, which cannot be developed by a new venture alone (Mapes, 1967). Universities also provide consulting assistance to a new venture and opportunities for continuing education for professional employees (Cooper, 1973). In the long run, the collaboration can enable new ventures to recruit researchers with high caliber who will not join the venture otherwise. In the collaboration process, professors and researchers are personally acquainted with the venture and thus recommend their students/fellow young researchers to join the venture. In addition, graduate students who participate in the projects can get to know about the venture and its technology and are likely to join as key members of the venture when they believe the success potential of the venture. As expected, interviews with the founders of successful technology-based Korean ventures indicate that the founders actively used the collaboration with universities and research institutes for developing technology as well as for hiring high-quality employees.

Participation in venture associations and informal entrepreneurs' network help a firm to establish relationship with other young organizations and established companies. By participating in venture associations and informal entrepreneurs' networks, entrepreneurs can obtain valuable information about management of venture business, new market trends and opportunities, and potential cooperators (Pennings and Harianto, 1992). The networks also help entrepreneurs find right professionals such as lawyers, accountants, and venture capitalists who can help the ventures, since networks can function as powerful referring networks. The reference will be more valuable when it has a solid ground to believe the 
referee because of two reasons. First, information transferred through trustworthy relations is more credible and interpretable, because the identity of actors and the intensity of their social ties are as important as the information itself (Uzzi, 1996). Second, the network functions as a social control mechanism, because the network diffuse information about economic actors, and the fear of reputation loss resulting from opportunistic behavior deters firms linked to the network from behaving opportunistically against each other (Raub and Weesie, 1990). Since repeated contacts in venture associations and informal networks help participants to build trustworthy relations and strengthen the network's function of social control mechanism, the repeated contacts enhance the value of reference.

These discussions lead us to following hypothesis.

Hypothesis 4: The partnership-based linkages to other firms, venture capital companies, universities/research institutes and venture association are positively associated with organizational performance.

Sponsorship-based linkages. Sponsorship-based linkages of an organization are unilateral relationships in the sense that external entities provide supports to the organization without receiving explicit rewards. Young organizations that are supported by powerful institutes have a substantial advantage (Flynn, 1993; Stuart et al., 1999). Faced with great uncertainty about the financial prospects of business ventures, third parties rely on the prominence of the sponsors of those ventures to make judgments about their prospects. The linkages thus increase the amount of external resources available to a new venture, providing the opportunity for organizational growth. Reducing the potentially adverse effects that arise during vulnerable early stage of the organization (Stinchcombe, 1965), the linkages protect the new ventures from environmental threats (Hall, 1982; Miner, Amburgey, and Sterns, 1990). Young organizations can mobilize resources from those institutes free of charge or with better terms. The sponsorship of those institutes also enhances the social legitimacy and status of a new venture (Baum and Oliver, 1991; Podolny, 1993; Rao, 1994; Stuart et al., 1999). The enhanced legitimacy and status enable a 
new venture to mobilize resources from third parties that are critical for venture success.

In the context of technology-based Korean business ventures, the Korean government has initiated creating a richer and more nurturing environment conductive to birth and survival of technology-based ventures. The government itself nominated several technology-based ventures as promising ones and provided research funding for technology development to those ventures. When selected as a promising small enterprise by the government, the venture can obtain a developmental fund from the government and social legitimacy.

The Korean government also encouraged powerful financial institutions to provide more supports to technology-based ventures. Several commercial banks in Korea have established the promising small enterprise nomination programs. When selected as a promising small enterprise by a bank, a new venture can borrow money with an interest rate lower than market rate and also get social legitimacy. These discussions lead us to following hypothesis.

Hypothesis 5: The sponsorship-based linkages to venture capital, commercial banks, and government agencies will increase organizational performance.

Interactions. Above hypotheses suggest that internal capabilities and linkages to external entities individually influence organizational performance. While internal capabilities indicate organization's ability to transform inputs into outputs efficiently, corporate social capital - organization's linkages to external entities - determines ability to mobilize inputs needed for transformation and to dispose outputs (Burt, 1992; Pennings et al., 1998). Internal capabilities help a firm to build social capital, since a firm with a higher level of distinctive capabilities is more likely to be selected as a networking partner by other firms (Chung, Singh, and Lee, 2000). Corporate social capital also facilitates the accumulation of internal capabilities, because other firms linked to the focal firm offer access to valuable information, resources, and economic opportunities that are necessary for the accumulation of internal capabilities (Knoke, 1999). 
Organization of which transformation capabilities are much greater than capabilities for garnering inputs and disposing outputs cannot fully utilize its transformation capabilities, since it has a difficulty in mobilizing necessary inputs from environment and in disposing outputs at a reasonable price. When the quality of the outputs and the value of transformation capabilities can be accurately measured without substantial cost, external entities can rely on the measurement in deciding whether they will transact with the focal firm. When the measurement is not easy as in the case of the outputs of technology-based business ventures, even a firm with a high level of transformation capabilities is not able to acquire extramural resources. It is because external entities face a great deal of uncertainty in assessing the value of transformation capabilities and potential outputs.

Organization of which capabilities for garnering inputs and disposing outputs are much greater than transformation capabilities cannot acquire necessary inputs and dispose outputs in the long run. Social relations in which exchange between actors are not reciprocal for a long time are likely to be broken, since one actor unilaterally sacrifices itself for the other for a long time (Chung et al., 2000; Gouldner, 1960; Levi-Strauss, 1957). External entity that has exchange relations with a focal firm lacking transformation capabilities does not have strong incentive to maintain its relationship for a long time. In sum, organizations that keep the balance between internal capabilities and social capital can fully utilize them and thus can perform well. These discussions lead us to the following hypothesis.

Hypothesis 6. Internal capabilities and linkages to external entities will have positive interaction effect on organizational performance.

\section{METHODS}

\section{Sample}

The population of our study is technology-intensive young Korean firms, especially called new business ventures. The ideal data would have been drawn from the total population of 
new business ventures in Korea. Since it was not feasible to draw a random sample from such a broad population, we sampled firms from those that were enrolled as a new business venture in Korean Small and Medium Business Administration (KSMBA). If a firm was enrolled as a new business venture, the firm could enjoy various benefits from the government such as a favorable tax break. A firm whose total number of employees is less than 300 could apply for the enrollment. The KSMBA certified applying firms that satisfy one of the following four criteria: (1) firm that venture capitalists have more than $10 \%$ of firm's equity, (2) firm that invested more than $5 \%$ of its sales volume in R \& D activities, (3) firm that produce product/services by applying patent technologies or copy right, and (4) firm that begins with new technology development projects that the Korean government supported financially.

We sampled technology-based young firms from those enrolled in KSMBA by employing three criteria: (1) industrial scope, (2) age of the firm, and (3) independent start-up not spin-off from internal corporate venturing within large companies. To select technology intensive firms, we sampled firms of which major industrial segments are computer software, biotechnology, or electric, electrical and electronic product and equipment. To select young business venture, we removed firms that were founded before 1983. We used the third criterion since new start-ups might be very different from spin-offs from large companies. At the end of 1998, 2043 firms were enrolled as business ventures in KSMBA. By applying the above criteria, 1012 firms were selected as our sample firms.

\section{Data Collection}

We used survey questionnaire as a major data collection tool. The data collection procedures are as follows. First, we designed a data collection instrument that could effectively gather data on relevant variables. Second, we pooled the results of the first phases with personal interviews and survey literature to conduct a nationwide mail survey of chief executives or founders.

The questionnaire performs the actual interrogation function in a mail survey and 
therefore warrants considerable attention. The design and administration of the questionnaire in this study relied on the "total design method" of Dilman (1978) and Parkhe (1993) who used social exchange theory to develop various ways to encourage response. We implemented most of those suggestions. To generate measurement items that influence organizational performance, we first reviewed literature in resource-based view of the firm and social capital theory, and then investigated organizational characteristics of 128 successful Korean ventures business by reviewing business magazines, newspapers, and brochures distributed by new ventures. We interviewed top executives and upper echelon managers of 50 firms to refine measurement items.

To assess the face validity of the measurement items, some of which were developed specifically for this study because of the paucity of prior empirical work in this area, we used business school faculty members and doctoral students as expert judges After several iterations of item editing and refinement, we conducted pretest interviews with 3 entrepreneurs and 2 venture capitalists in Seoul, Korea to identify any problems with question wording and questionnaire layout. These interviews, which ranged from 90 to 120 minutes, yielded many useful suggestions that strengthened the content and concurrent validities of the instrument. And we also pretested our questionnaire by using 11 firms in December 1998.

We sent the questionnaire to the CEO or founding members. We targeted entrepreneur and CEO of the firm first, and founding members second. These individuals were chosen because of their extensive knowledge of their firm's organizational characteristics. Considering smallness and newness of our sample firms, they were very likely to have correct information (Castrogiovanni, 1992; Chandler and Hanks, 1994). Also questioning factual information rather than perceptual information would enhance the accuracy and validity of our data. The key informant method has been commonly used in organizational research when secondary archival data were not likely to be available (Hansen and Wernerfelt, 1993).

Following suggestions of Dilman (1978) and Parkhe (1993), we took the following sequential steps to maximize response rate: (1) made phone calls to executives of our 
sample firms for explaining the objectives of this research projects and requesting their cooperation just after we sent the questionnaire, (2) sent a letter convincingly explaining the objectives of this research projects and requesting corporation, and (3) mailed a second wave of surveys to nonrespondents

\section{Respondents}

We sent questionnaire to all of the 1012 firms. Of the 1012 firms, 88 questionnaires were returned because of ambiguous address or moving schedule. Of the 924 firms receiving questionnaires, 175 firms (19 \% response rate) responded to the questionnaire. The respondents were followed by phone calls to clarify any incomplete data. To reduce unobserved heterogeneity, we deleted 19 firms that were founded by a joint venture of large Korean conglomerates or founded before 1983. We also deleted 13 additional responding firms due to missing information. As a result, we used data from 143 firms (17\% usable responses). This response rate is similar to the 15-24 percent range reported in similar published studies (e.g., John, 1984; Provan and Skinner, 1989) and was especially satisfactory considering the study's requirement for senior executive's direct involvement and the sensitivity of some question items. 102 firms indicated that their top executive responded the questionnaire, and remaining 41 firms pointed out that top echelon managers filled out the questionnaire.

Possible nonresponse bias was examined by comparing the characteristics of 143 survey respondents with 131 nonrespondents that were randomly sampled from nonresponding firms. We collected the number of total employees of year 1997 and total asset variable of year 1998 of the sampled nonresponding firms from KSMBA website. A one-way analysis of variance (ANOVA) showed that size difference (F-value 1.620) and total asset difference (F-value .890) between respondents and nonresponding firms are not statistically significant.

\section{Threats to Validity and Countermeasures}


Using questionnaires for collecting firm-level data has potential weakness. To check the reliability and validity of our data, we conducted following procedures. First, we_asked factual (not perceptual) information whenever possible, since subjective measurement that most of prior empirical studies (e.g., Chandler and Chandler, 1994; Jennings and Lumpkin, 1989) used can produce common method bias. Several scholars have criticized subjective measurement organizational attributes such as measurement using Likert-Scales (e.g., Dess and Keats, 1987). Since the subjective measures will not reflect the objective organizational attributes, respondent's characteristics such as personality and social desirability can bias his judgment. To avoid this common method bias, we tried to collect objective measures, whenever possible.

$\underline{\text { Second, we checked the reliability of our data by mailing an identical questionnaire }}$ to alternate senior executives from a random subset $(\mathrm{N}=50)$ of the responding firms. Fourteen executives returned these independently completed questionnaires. Significant, positive correlations between the responses provided strong evidence of inter-rater reliability. This high degree of agreement between multiple respondents strengthened confidence in the survey's validity.

Third, we triangulated reported data with secondary data (cf. Keats and Hitt, 1988). Since the information on most variables of interest in this study was not available from published sources, independent corroboration of all questionnaire items is not possible. Therefore we corroborated our data with selected variables that are publicly available. We collected the archival record of sales volume, total assets, and the number of employees of respondents from KSMBA web sites and compared the secondary data with reported data. The congruence of data obtained in 126 of the 135 cases (93.3\%) supports the validity of the selected variable and may also reflect favorably on the likely accuracy of other reported data.

Finally, we used scale reordering suggested by Salancik and Pfeffer (1977). The scale reordering seeks to reduce the effects of consistency artifacts by arranging the items on a self-report questionnaire so that measures of the dependent variables follow, rather 
than precede, the independent variables. We followed this method, by placing the organizational performance measures after the measures of firm resource and social capital variables.

\section{Measurement of Internal Capabilities}

We measured internal capabilities by three variables; entrepreneurial orientation, technological resources, and financial resource invested.

Entrepreneurial orientation. Following suggestions of Miller (1983), Covin and Slevin (1991), and Stevenson and Jallio (1990), we measured entrepreneurial orientation by three dimensions: innovativeness, risk-taking propensity, and proactiveness. First, following suggestion of Lumpkin and Dess (1996), we measured innovativeness as the number of R\&D employees divided by the total number of employees in 1997. Second, we measured risk-taking propensity by two indicators; (1) the number of risky R\&D projects divided by the total number of $R \& D$ projects in 1997 and (2) $R \& D$ expenditure per risky R\&D project (total risk-taking R\&D expenditure / the total number of risk-taking projects in 1997). The heavy resource commitment on risky project is consonant with the definition of risk- taking propensity. We treated a project for developing a brand new product as a risky $R \& D$ project. To create a single measure for the risk-taking propensity, we standardized two indicators by using mean and standard deviation of the corresponding indicator and added the two standardized scores. Third, proactiveness was captured index by the ratio of market research costs and advertising expenses to sales volume. To create a single composite indicator for entrepreneurial orientation, we standardized indicators of the above three dimensions and added them up.

Technological capabilities. We measured technological capabilities by three indicators; (1) the number of technologies that are internally developed, including the number of patents and patents submitted, (2) the number of utility model patents and designs that were registered to the Korean Patents Administration, and (3) the number of foreign and domestic quality assurance marks acquired. We standardized each of the 
indicators by using the mean and standard deviation of corresponding indicator and added them up to create a single indicator. Since the average age of our sample firms are 3 years and acquiring a patent usually takes three or more years in Korea, we could not use the number of patents only.

Financial resources invested. Schoonhoven et al. (1990) measured financial resources invested with monthly average of total costs and expenses accrued after organizational founding. We measured financial resources by three indicators: the amount of total R\&D investment, advertising expenditure, and market research investment in 1997. We added them up to make one index. The logic is that organizational performance largely depends on the amount of financial resource invested during the previous year.

\section{Measurement of Linkages to External Entities}

Partnership-based linkages. We measured partnership-based linkages by four indicators, drawing on prior literature and interviews with entrepreneurs. The first indicator is the number of other firms with which a focal firm has a strategic alliance for marketing or technology development. The second is the number of venture capital firms that invested equity in the focal firm. The third is the number of collaborating R\&D projects and technology exchange programs with universities or research institutes. The forth indicator is the number of formal associations for entrepreneurs and informal entrepreneur's network that a focal firm participates in.

Sponsorship-based linkages. We measured sponsorship-based linkages by two indicators. The first indicator reflects sponsorship from commercial bank. It is measured by two index; (1) the number of cases in which financial institutes named the focal firm as a promising small enterprise, and (2) the number of financial institutes from which the focal firm received a loan with a below market interest rate during 1997. We standardized each

of the two indicators by using the mean and standard deviation of corresponding one and added them up to create a single indicator. The second indicator reflects sponsorship from the Korean government agencies is measured by two index; (1) the number of cases in 
which Korean central or local governments named the focal firm as a promising small enterprise, and (2) the number of government research projects that the focal firm executed alone or with other organizations during 1997. We standardized each of the two indicators by using the mean and standard deviation of corresponding one and added them up to create a single indicator.

\section{Measurement of Organizational Performance}

How can we measure the performance of new business ventures? Profitability such as return-on-investment may not be an appropriate performance indicator for new business ventures, because many of them are usually in the stage of product development (Hart, 1995). In addition, it is very difficult to gather accurate accounting data, since many of those firms did not establish an accurate formal accounting system yet. We could not use the speed of shipping first product for revenues after foundation (Schoonhoven et al, 1990), organizational growth (Eisenhardt and Schoonhoven, 1990) or organizational survival (Brüderl, Preisendörfer, and Ziegler, 1992), since we did not have firm level data from the founding. After interviewing top managers of our sample firms and considering prior studies on venture performance, we decided to use competitiveness of products/services to reflect the fact that entrepreneurs usually found new business ventures with the objectives of out-competing or replacing existing companies or creating a new market niche. These characteristics of entrepreneurial strategy can be captured by their products/services in sale.

To measure the competitiveness of products/services, we asked five questions asking the number of (about) the competitiveness of products/services that the focal firm sold in 1998; (1) the number of products/services of which performance or quality was significantly improved in 1998, (2) the number of products/services of which production-cost-competitiveness was significantly enhanced in 1998, (3) the number of products/services that created a new market niche in 1998, (4) the number of products/services that penetrated established market successfully in 1998, and (5) the number of products/services that significantly substituted import from foreign countries in 
1998. We added the five numbers and divided it by the total number of products/services that the focal firm was selling in 1998. The average ratio indicates the percentage of products/services that had or improved competitiveness. But, since the ratio itself does not inform us financial contribution to the focal firm, we multiplied the ratio by sales volume in 1998. Sales volume data for each of products/services with competitiveness would be more desirable, but we could not gather those data. Therefore, we estimated the sales volume of products/services with competitiveness by multiplying the ratio and sales volume. The measurement error would produce less significant coefficients for independent variables, and likely to generate conservative bias in interpreting results.

\section{Control variables}

We controlled for variables that may affect organizational performance besides organizational capabilities and corporate social capital. Variables controlled for are the number of employees, firm age, environmental munificence, and entrepreneur's industry experience at the end of 1997. We controlled for organizational age that is the number of years elapsed after founding since it would positively influence performance as "liability of newness” arguments suggest (Stinchcombe, 1965).

Prior studies suggested that environmental munificence such as the quality of the opportunity has a significant direct impact on venture performance (Casrogiovanni, 1991; Chandler and Hanks, 1994). Researchers have stated that opportunities are more abundant when market demand is growing rapidly (Hofer, 1975; Yip, 1982; Hambrick and Lei, 1987), and industry competition is relatively unconcentrated (Buzzell and Gale, 1987; Biggadike, 1979; Sandberg, 1986). We controlled for the average growth rate of market that the focal firm participated in during 1997 and the number of competing firms in 1997, since they can indicate environmental munificence (Chandler and Hanks, 1994; Schoonhoven et al. 1990).

Prior studies also suggested that start-up firms are an extension of the entrepreneurs, and that the characteristics of entrepreneurs affect organizational performance. Since the industry experience of entrepreneur is a very important predictor of 
venture performance (Brüderl, Preisendörfer, and Ziegler, 1992), we controlled the length of entrepreneur's industry experience.

\section{Analysis}

As we already mentioned in measurement section, we adopt lagged dependent variable model in order to specify the relationship between firm's resource/social capital and organizational performance. We lagged the effect of independent variables at least one year. Dependent variables were the competitiveness of products/services measured in 1998, while independent variables were either 'stock' indicators at the end of 1997 or 'flow' indicators before the end of 1997. We selected the length of lagging effect on the basis of interviews with top executives. The lagged dependent variable model would be a more rigorous test of the effects of firm characteristics on firm performance (Mosakovski, 1993).

We employed ordinary least squares (OLS) regression to analyze the data. In order to test the additive effects of internal capabilities, external linkages, and the interaction between internal capabilities and external linkages, we ran four different models for each dependent variable. The first model with only control variables is a benchmark against which to test the effects of internal capability on organizational performance. The second model has both control variables and internal capabilities in order to test positive global effects of complementarity in comparison to the first model. The third adds external linkages to the second model. The last model is a full model that includes control variables, internal capabilities, external linkages and interaction terms. It tests the additive effects of interaction terms on alliance formation relative to the third model.

\section{RESULTS}

Table 1 provides the means, standard deviations, and correlations of all variables. Positive and significant correlations between internal capability indicators and social capital indicators suggest that internal capabilities can help the development of social 
capital and vise versa. Also notable are positive and significant correlations among social capital indicators. Table 2 and 3 reports the results of four regression models explaining sales volume and competitiveness of services/products respectively.

\section{Insert Table 1 about Here}

Global tests. We conducted a series of global tests comparing successive models by using incremental F-test, as shown in the bottom of Table 2 and 3. The first global test indicates that Model II, which includes internal capabilities, as well as control variables, explains the sales volume and the competitiveness of services/products significantly better than Model I, which has control variables only $(\mathrm{p}<.001)$. Also, the second global test indicates that Model III, which uses external linkages, explains the dependent variables significantly better than Model II $(\mathrm{p}<.001)$. The final global test shows that addition of interaction terms significantly improves explaining power of the model $(\mathrm{p}<.001)$. These global tests indicate that we have to consider internal capabilities, external linkages, and their interaction terms together to explain the performance of technology-based young organizations better.

\section{Insert Table 2 about Here}

\section{Insert Table 3 about Here}

Internal capabilities. We can test each of the hypotheses on the basis of the Model IV results. Hypothesis 1 suggests that internal capabilities of organization is positively associated with organizational performance. As the hypothesis predicts, financial resources invested positively influence both indicators of organizational performance. Entrepreneurial orientation does not have any significant effect on the dependent variables in Model IV. Contrary to the hypothesis, technological capabilities significantly decrease both indicators of organizational performance in Model IV. While the variable has 
significant and positive effect on the dependent variables in the other models, the positive coefficient becomes negative one when we introduce interaction terms in Model IV. Hypothesis 1 is not supported.

External Linkages. Hypothesis 2 suggests that linkages to external entities is positively associated with organizational performance. As the hypothesis predicts, linkages to other enterprises and venture capital companies have positive and significant influence on both indicators of organizational performance. Contrary to the hypothesis, linkages to commercial banks significantly decrease both indicators of the dependent variables. Linkages to government significantly decrease sales volume but significantly increase product competitiveness. Linkages to universities/research institutes do not have any effect on sales volume but have significantly negative effect on product competitiveness.

Interactions between internal capabilities and external linkages . The effect of interaction terms are mixed in general. Several interaction terms have positive influence on organizational performance, while other terms have negative influence on the dependent variables.

\section{DISCUSSION AND CONCLUSIONS}

This study provides several theoretical and practical implications for researchers and managers who are concerned with new business ventures. First of all, this study confirmed (showed) the importance of financial capital invested and technological capabilities. Financial resources invested are as important as technological resources in determining organizational performance in the context of new business ventures. Generally most of researchers in RBV agree that financial resources are seldom the source of sustainable competitive advantages, but star-up entrepreneurs see that financial rexource is the key to getting into business (Dollinger, 1995; 30). Also the venture managers have to develop and accumulate technological capabilities and to accurately assess market opportunities for venture success. Thus that the suggestions of the resource-based view that certain types of resources will lead to organizational 
performance is consistent with our findings. Especially in the context of new business ventures, we conclude that the types of resource such as technological capabilities and financial resources are very important firm resource to increase competitive advantages. Theses internal capabilities are valuable, rare or unique, inimitable, and nonsubstitutable in the context of new business ventures. Emphasis on uniqueness of a firm's resources and the relationships of them to firm's competitiveness is shared by many researchers within the resource-based tradition. The Entrepreneurial orientation has an impact on venture performance within model 2 but not within model 4. The Entrepreneurial orientation has an impact on venture performance but relatively less important than technological capabilities and financial resource.

Second, the results of this study showed that linkages to external entities are very important for venture success as social capital theory suggested. Among various linkages, strategic alliances with venture capital companies, suppliers and customers are critical for venture success. Sponsorship-based relationships have partial impact on venture performance but relatively are not more important for enhancing organizational performance rather than partnership-based linkages. This study suggests that for new venture success, entrepreneurs should be more interested in make partnership-based social capital based on internal capabilities.

Third, this study showed that there are very strong interaction effects of internal capabilities and linkages to external entities. Some prior research tried to proved the importance of external linkages, and others investigated the effects of internal firm resource on organizational performance. In other words, most of prior studies on new business ventures investigated the impact of internal capabilities and social capital on performance separately, but this study suggest that two theories need to be complementary considered and integrated. The results of this study suggest that the entrepreneurs of new business ventures should simultaneously develop internal capabilities and social capital.

Forth, this study empirically tested and supported the causal relationship between internal capabilities/social capital and organizational performance through 
lagged dependent variable model. Thus we can suggest that the resource-based view and social capital theory are useful theory for exploiting, explaining and predicting the determinants of new business venture's performance with a view to organizational capabilities.

The weakness of this study provides some suggestions for future research. First, this study focused on the formal inter-organizational relationships. Future research needs to consider informal inter-organizational relationships or social network such as entrepreneur's and founding team's personal networks(Dubini and Aldrich, 1991; Ostggard and Birley, 1994; Flood et al., 1997). The study of analyzing both of them could reveal the dynamics of external resource mobilization through social networks and furnish comprehensive results about external resource mobilizing of capabilities.

Second, future research can examine conditions under which the interaction effects of internal capabilities and corporate social capital are more prevalent. We claimed that difficulty in evaluating the outputs of a firm and the firm itself increases the strength of interaction effects. The results of this study showed that the interaction effects are very strong in the current setting, but did not showed that they are not strong in other less uncertain conditions. The performance generated by an interaction of internal capabilities and social capital will also depend on conditions in a firm's competitive and general environment.

Third, this study did not investigate the relationships of each variables of internal capabilities and external linkages. For example we can consider that first entrepreneurial orientation have impact on technological capabilities and financial resource and then they affect venture performance. Also we need to investigate that the performance will depend on relationship between one resource and the other resources held by the firm. If a resource is more specified and specialized to other resources of the firm, it may yield higher organizational performance (Conner, 1991; Mosakowski, 1993)

Forth, this study investigated defined and restricted internal capabilities and 
social capital. There can be another type of internal capabilities and social capital. Future research necessary has to exploit other kind of firm resource and social capital for new business ventures.

Fifth, we could not use longitudinal methodology due to limitations in collecting data. Future research can collect data from the founding of sample firms and investigate other kinds of performance indicators such as survival, growth rate, and time interval between founding and the shipment of first commercial product for generating revenue. 


\section{Reference}

Aldrich, H. E. and E. R. Zimmer. (1986). 'Entrepreneurship through social network'. In D. L. Sexton and R. W. Smilor (eds.), The art and science of entrepreneurship. Ballinger Publishing, Cambridge, MA, pp.3-24.

Barney, J. B. (1986a). 'Organizational culture: Can it be a source of sustained competitive advantage?’, Academy of Management Review, 29(2), pp. 656-665.

Barney, J. B. (1986b). 'Strategic factor markets: Expectation, luck, and business strategy', Management Science, October, pp.1231-1241.

Barney. J. B. (1991). 'Firm resources and sustained competitive advantage', Journal of Management, 17, pp. 99-120.

Baum, J. A. C. and C. Oliver (1991). 'Institutional linkages and organizational mortality', Administrative Science Quarterly, 36(2), pp.187-219.

Bettis, R. A. and M. A. Hitt (1995). 'The new competitive landscape', Strategic Management Journal, Special Issue, 16, pp. 7-20.

Biggadike, R. (1979). 'The risky business of diversification', Harvard Business Review, May-June, pp.103-111.

Birley, S. (1985). 'The role of networks in the entrepreneurial process', Journal of Business Venturing, 1, pp. 107-117.

Boeker, W. (1989). 'Strategic change : The effects of founding and history', Academy of Management Review, 32(3), pp. 489-515.

Brockhaus, R. H. (1982). 'The psychology of entrepreneur'. In C. A. Keneth, D. L. Sexton and K. H. Vesper (eds.), Encyclopedia of entrepreneurship. Prentice Hall, Englewood Cliffs, NJ, pp. 39-72.

Brüderl, J., P. Preisendörfer and R. Ziegler (1992). 'Survival chances of newly funded business organizations’, American Sociological Review, 57, pp. 227-242.

Burt, R. S. (1992). Structural holes. Harvard University Press, Cambridge, MA.

Buzzell, R. D. and B. T. Gale (1987). The PIMS principles: Linking strategy to performance. Free Press, New York.

Campbell, D. T. and D. W. Fiske (1959). 'Convergent and discriminant validation by the the multitrait-multimethod matrix’, Psychological Bulletine, 56, pp.81-105.

Castrogiovanni, G. J. (1991). 'Environmental munificence: A theoretical assessment', Academy of Management Review, 16(3), pp.542-565.

Caves, 1984

Caves, R. E. (1980). 'Industrial Organization, corporate strategy and structure', Journal of Economic Literature, 58, pp. 64-92.

Caves, R. E. (1985). 'International trade and industrial organization: Problems, solved and unsolved', European Economic Review, 28, pp. 377-396.

Chandler, G. N. and S. H. Hanks (1994a). 'Founder competence, the environment and venture performance', Entrepreneurship: Theory and Practice, 18(3), pp.77-90.

Chandler, G. N. and S. H. Hanks (1994b). 'Market attractiveness, resource-based capabilities, venture strategies and venture performance', Journal of Business Venturing, 9(4), pp. 331-350. 
Chung, Singh \& Lee, 2000

Conner, K. R. (1991). 'A historical comparison of resource-based theory and five schools of thought within industrial organization economics : Do we have a new theory of the firm?', Journal of Management, 17, pp.121-154.

Cooper \& Bruno, 1977

Cooper, 1973

Cooper, A. C. (1971). The founding of technologically-based firms. The Center for Venture Management, Milwaukee, WI.

Cooper, A. C. and A. V. Bruno (1975). 'Predicting performance in new high-technology firms', Proceedings of the $35^{\text {th }}$ Annual Meeting of the Academy of Management, August, pp. 426-428.

Covin, J. G. and D. P. Slevin (1989). 'Strategic management of small firms in hostile and benign environments’, Strategic Management Journal, 10, pp.75-87.

Covin, J. G. and D. P. Slevin (1991). 'A conceptual model of entrepreneurship as firm behavior’, Entrepreneurship: Theory and Practice, 16(1), pp. 7-24.

Dess, G. G. and B. W. Keats (1987). 'Environment assessment and organizational performance: An exploratory field study', Paper presented at the annual meeting of the Academy of Management, New Orleans.

Dierickx, I. and K. Cool (1989). 'Asset stock accumulation and sustainability of competitive advantage', Management Science, 35, pp. 1504-1511.

Dilman, D. A. (1978). Mail and telephone surveys : the total design method. John Wiley \& Sons, New York.

Dollinger, M. J. (1984). 'Environmental boundary spanning and information processing effects on organizational performance', Academy of Management Journal,27(2), pp. 351-368.

Dollinger, M. J. (1985). 'Environmental contacts and financial performances of the small firm’, Journal of Small Business Management, 23, pp. 24-31.

Dollinger, M. J. (1989).

Dollinger, M. J. (1995). Entrepreneurship: Strategies and resources. Irwin, Boston.

Dubini, P. and H. E. Aldrich (1991). 'Personal and extended networks are central to entrepreneurial process’, Journal of Business Venturing, 6(5), pp. 305-313.

Eisenhardt, K. M. and C. B. Schoonhoven (1990). 'Organizational growth: Linking founding team strategy, environment, and growth among U. S. semiconductor ventures, 1978-1988', Administrative Science Quarterly, 35(3), pp. 504-530.

Eisenhardt, K. and L. Bourgois (1988). 'Politics of decision making in high-velocity environments: Toward a mid-range theory’, Academy of Management Journal, 31, pp. 737-770.

Flynn, D. M. (1993). 'Sponsorship and the survival of new organizations', Journal of Small Business Management, 31, pp. 51-63.

Gabbay \& Leenders, (1999)

Ginsberg, A. (1985). 'Measuring changes in entrepreneurial orientation following industry deregulation : The development of a diagnostic instrument', Proceedings of the International Council of Small Business, pp. 50-57. 
Goodstein \& O’Reilly, (1988)

Goulder, (1960)

Granovetter, M. S. (1985). 'Economic action and social structure: The problem of social embeddedness', American Journal of Sociology, 31, pp. 481-510.

Hagedoorn, J. (1993). 'Understanding the rationale of strategic technology partnering: Interorganizational modes of cooperation and sectoral difference', Strategic Management Journal, 14, pp. 371-385.

Hall, R. (1991). 'The contribution of intangible resources to business success', Journal of General Management, 16(4), pp. 41-52.

Hall, R. (1993). 'The strategic analysis of intangible resource', Strategic Management Journal, 13, pp. 135-144.

Hambrick, D. C. and D. Lei (1985). 'Toward an empirical prioritization of contingency variables for business strategy', Academy of Management Journal, 28, pp.763-788.

Hamel, G., Y. Doz and C. Prahalard (1989). 'Collaborate with your competitors and win', Harvard Business Review, January-February, pp. 133-139.

Hannan \& Freeman, (1985)

Hansen, (1995)

Hansen, G. S. and B. Wernerfelt (1993). 'Determinants of firm performance: The relative importance of economic and organizational factors’, Strategic Management Journal, 10, pp. 399-412.

Harman, H. H. (1967). Modern factor analysis. University of Chicago Press, Chicago.

Hart, M. M. (1995). 'Founding resource choices: Influence and effects on entrepreneurs and venture capital', Harvard University, DBA degree.

Henderson \& Clark (1990)

Hennart, J. (1991). 'The transaction costs theory of joint ventures: An empirical study of Japanese subsidiaries in the United States', Management Science, 37, pp. 483-497.

Hill, C. W. L., M. A. Hitt and Hoskinson, R. (1992). 'Cooperative versus competitive structures in related and unrelated diversified firms', Organization Science, 3, pp.501-521.

Hofer, C. W. (1975). 'Toward a contingency theory of business strategy', Academy of Management Journal, 18, pp.784-810.

Huber, G. P. and D. J. Power (1985). 'Retrospective reports of strategic level managers: Guidelines for increasing their accuracy’, Strategic Management Journal, 6, pp.171-180

Jennings, D. F. and J. R. Lumpkin (1989). 'Functioning modeling corporate entrepreneurship: An empirical integrative analysis’, Journal of Management, 15(3), pp.485-503.

Kao, Raymond W. Y. (1995). Entrepreneurship: A wealth-creation and value-adding process. Prentice-Hall, New York.

Kazanjian, R. K. (1988). 'Relation of dominant problems to stage of growth in technology-base new ventures', Academy of Management Journal, 31(2), pp. 257-280.

Keats, B. W. and M. A. Hitt (1988). 'A causal model of linkages among environmental dimensions, macro organizational characteristics and performance', Academy of Management Journal, 31, pp.570-598. 
Leenders \& Gabby, (1999) Corporate Scocial capital. New York: Kluwer Academic Publishers.

Levi-Strauss, (1957)

MacKenzie, S. B., P. M. Podsakoff and R. Fetter (1991). Organizational Citizenship behavior and objective productivity as determinants of managerial evaluations of salesperson's performance', Organizational Behavior and Human Decision Process, 50, pp.123-158.

Maidique, M. and P. Patch (1982). 'Corporate strategy and technological policy'. In M. Tushman and W. Moore (eds.), Readings in the management of innovation. Pitman Marshfield, MA, pp. 273-285.

Mapes, (1967)

Miller, D. (1983). 'The correlates of entrepreneurship in three types of firms', Management science, 29, pp. 770-791.

Miller, D. and J. Shamsie (1996). 'The resource-based view of the firm in two environments: The Hollywood film studios from 1936 to 1965', Academy of Management Journal, 39(3), pp.519-544.

Miller, D. and P. Friesen (1978). 'Archetype of strategy formulation', Management Science, 24, pp. 921-923.

Miner, A., J. Amburgey and T. Sterns (1990). 'Interorganizational linkages and population dynamics: Buffering and transformational shields', Administrative Science Quarterly, 35, pp. 685-713.

Minzberg, H. and J. A. Waters (1985). 'Of strategy, deliberate and emergent', Strategic Management Journal, 6, pp. 257-272.

Morris, M. H. and G. W. Paul (1987). 'The relationship between entrepreneurship and marketing in established firms', Journal of Business Venturing, 2(3), pp. 247-259.

Mosakoswski, E. (1993). 'A resource-based perspective on the dynamic strategy-performance relationship: An empirical examination of the focus and differentiation strategies in entrepreneurial firms', Journal of Management, 19(4), pp. 819-839.

Nohria, N. (1992). 'Introduction: Is a network perspective a useful way of studying organizations'. In N. Nohria and R. Eccles (eds.), Network Organizations: Structure, form and action. Harvard Business School Press, Boston MA, pp. 1-22.

Ostggard, T. A. and S. Birley (1994). 'Personal networks and firm competitive strategy: A strategic or coincidental match?', Journal of Business Venturing, 9(4), pp.281-305.

Parkhe A. (1993). 'Strategic alliance structuring: A game theoretic and transaction cost examination of interfirm cooperation', Academy of Management Journal, 36(4), pp.794-829.

Pennings, J. M. and F. Harianto (1992). 'Technological networking and innovation implementation’, Organization Science, 3(3), pp.356-382.

Pennings, J. M. and F. Harianto (1992). 'The diffusion of technological innovation in the commercial banking industry', Strategic Management Journal, 13(1), pp.29-47.

Pennings, J. M. and K. M. Lee (1999). Mimicry and the market, Working Paper.

Pennings, J. M., K Lee and A. Witteloostuijn (1998). 'Human capital, social capital, and 
firm dissolution', Academy of Management Journal, 1.4(4), pp. 425-440.

Penrose, E. T. (1959). The growth of the firm. M. E. Sharpe, Inc., New York.

Peteraf, M. A.(1993). 'The cornerstones of competitive advantage: A resource-based view', Strategic Management Journal, 14, pp. 179-192.

Pfeffer, J. and G. R. Salancik (1978). The external control of organizations: A resource dependence perspective. Harper \& Row, Pub., New York.

Podolny, J. (1994).'Market uncertainty and the social character of economic exchange', Administrative Science Quarterly, 39, 1994, pp. 458-483.

Podsakoff, P. M., S. B. MacKenzie, R. N. Moorman and R. Fetter (1990). Transformational leader behavior and their effects on follower's trust in leader, satisfaction and organizational citizenship behaviors', Leadership Quarterly, 1(2), pp.107-142.

Posdsakoff, P. M. and D. W. Organ (1986). 'Self-reports in organizational research: Problems and prospects', Journal of Management, 12, pp.531-544.

Prahalad, C. K. and G. Hamel (1990). 'The core competencies of the corporation', Harvard Business Review, May-June, pp. 79-91.

Raub \& Weesie, 1990

Reed, R. and R. J. DeFllippi (1990). 'Causal ambiguity, barriers to imitation, and sustainable competitive advantage’, Academy of Management Review,15, 1990, pp. 88-102.

Romanelli, E. (1989). 'Environments and strategies of organization start-ups: Effects on early survival', Administrative Science Quarterly, 34(3), pp. 369-388.

Roure, J. and M. Maidique (1986). 'Linking prefunding factors and high technology venture success : An exploratory study’, Journal of Business Venturing, 1, 1986, pp.295-306.

Sandberg, W. R. (1986). New venture performance: The role of strategy and industry structure. Lexington Books, Lexington, MA.

Schafer, D. S. (1990). 'Level of entrepreneurship and scanning source usage in very small business', Entrepreneurship Theory \& Practice, 15(2), pp.19-31.

Schoonhoven, C. B., K. M Eisenhardt and K. Lyman (1990). 'Speeding products in market: Waiting time to first product introducing in new firms', Administrative Science Quarterly, 35(1), pp. 177-208.

Schumpeter, J. A. (1934). The theory of economic development. Harvard University Press., Cambridge, MA .

Schumpeter, J. A. (1947). 'The creative response in economic history', Journal of Economic History, 7, pp. 149-159.

Shrader, R. C. and M. Simon (1997). 'Corporate versus independent new ventures: Resource, strategy and performance differences’, Journal of Business Venturing, 12, pp. 47-66.

Stevenson, H. H. and J. C Jarillo (1990). 'A paradigm of entrepreneurship: Entrepreneurial management’, Strategic Management Journal, Special Issue, 11, pp. 17-27.

Stinchcombe, A. L. (1965). 'Social structure and organizations'. In James G. March (ed.), Handbook of Organizations. Rand Mcnally, Chicago, pp. 142-193.

Teece, D. (1987). 'Profiting from technological innovation: Implications for integration, 
Collaborating, Licensing, and public policy'. In D. Teece (ed.), The competitive challenge. Harper Collins, New York.

Tushman, M. and P. Anderson (1986). 'Technological discontinuities and organizational environments', Administrative Science Quarterly, 31, pp. 439-465.

Uzzi, B. (1996). 'The sources and consequences of embeddedness for the economic performance of organizations: The network effect', American Sociological Review, 61, pp. 674-698.

Van de Ven, A. H., R. Hudson and D. M. Schroder (1984). 'Designing new business startups entrepreneurial, organizational, and ecological considerations', Journal of Management, 10(1), pp.87-107.

Wernerfelt, B. (1984). 'A resource-based view of the firm', Strategic Management Journal, 5, pp. 171-180.

Yip, G. S. (1982). Barriers to entry: A corporate strategy perspective. Lexington Books, Lexington, MA.

Zahra, S. A. (1993). 'A conceptual model of entrepreneurship as firm behavior: A critique and extension', Entrepreneurship: Theory and Practice, Summer, pp.5-21. 
Table 1

Descriptive Statistics and Correlation Matrix ( $\mathrm{N}=143)$

\begin{tabular}{|c|c|c|c|c|c|c|c|c|c|c|c|c|c|c|c|c|}
\hline Variables & Mean & S.D. & 2 & 3 & 4. & 5. & 6. & 7. & 8. & 9. & 10. & 11 & 12 & 13 & 14 & 15 \\
\hline 2. Product competitiveness in 1998 & 15.5392 & 43.8540 & & & & & & & & & & & & & & \\
\hline 3. Entrepreneurial orientation of the firm & 0.0727 & 0.4763 & .21 & & & & & & & & & & & & & \\
\hline 4. Technological capabilities & -0.052 & 0.6209 & .52 & .00 & & & & & & & & & & & & \\
\hline 5. Financial resource invested & 569.60 & 1287.93 & .53 & .07 & .36 & & & & & & & & & & & \\
\hline 6. Linkages to other enterprises & 3.0070 & 5.3214 & -.03 & -.06 & .00 & -.00 & & & & & & & & & & \\
\hline 7. Linkages to venture networks & 0.9580 & 1.1313 & .16 & .05 & .18 & .54 & .11 & & & & & & & & & \\
\hline 8. Linkages to universities and research institutes & 1.9021 & 1.9548 & .15 & .01 & .35 & .07 & .33 & .20 & & & & & & & & \\
\hline 9. Linkages to venture capitalists & 0.4965 & 1.1313 & .55 & .07 & .35 & .66 & -.01 & .18 & .16 & & & & & & & \\
\hline 10. Linkages to financial institutes & -0.0295 & 0.8267 & .36 & -.12 & .43 & .21 & .03 & .23 & .16 & .35 & & & & & & \\
\hline 11. Linkages to government & -0.0257 & 0.9344 & .33 & -.10 & .49 & .27 & .07 & .34 & .13 & .39 & .62 & & & & & \\
\hline 12. Organizational size & 30.7692 & 43.6321 & .40 & -.16 & .44 & .73 & -.02 & .07 & -.00 & .64 & .50 & .54 & & & & \\
\hline 13. Organizational age & 4.5944 & 3.3802 & .17 & -.22 & .35 & .23 & .06 & .09 & .05 & .25 & .27 & .28 & .46 & & & \\
\hline 14. Entrepreneur's experience & 14.4406 & 7.2991 & .08 & -.04 & .18 & .08 & .01 & -.06 & .11 & .05 & .10 & .17 & .16 & .36 & & \\
\hline 15. Market growth rate & 89.2132 & 265.5017 & .06 & .27 & .04 & .02 & -.07 & -.05 & .15 & -.03 & -.01 & -.07 & -.05 & -.08 & .18 & \\
\hline 16. Number of competitors & 10.3038 & 17.4774 & .06 & .05 & .00 & .14 & .03 & -.02 & -.06 & .13 & .09 & .10 & .11 & .04 & .13 & .04 \\
\hline
\end{tabular}

Note $: \mathrm{p}<.05$ if $|\mathrm{r}|>.13$ 
TABLE 2

Results of OLS Models: Sales Volume in $1998(\mathrm{~N}=143)$

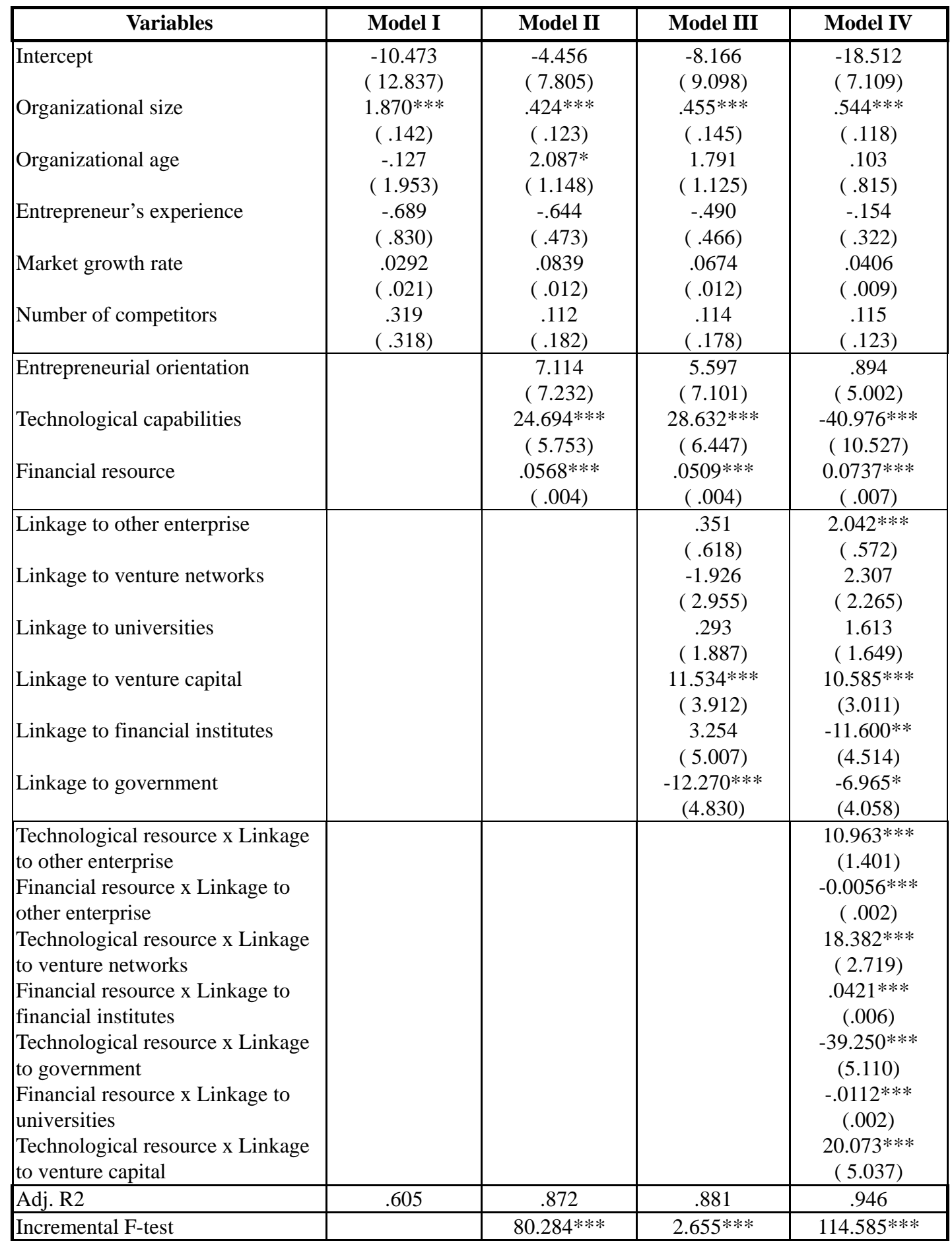

Note: Standard errors are in parentheses.

* $\mathrm{p}<.10$; ** $\mathrm{p}<.05$; *** $\mathrm{p}<.01$ 
TABLE 3

Results of OLS Models : Product Competitiveness in $1998(\mathrm{~N}=143)$

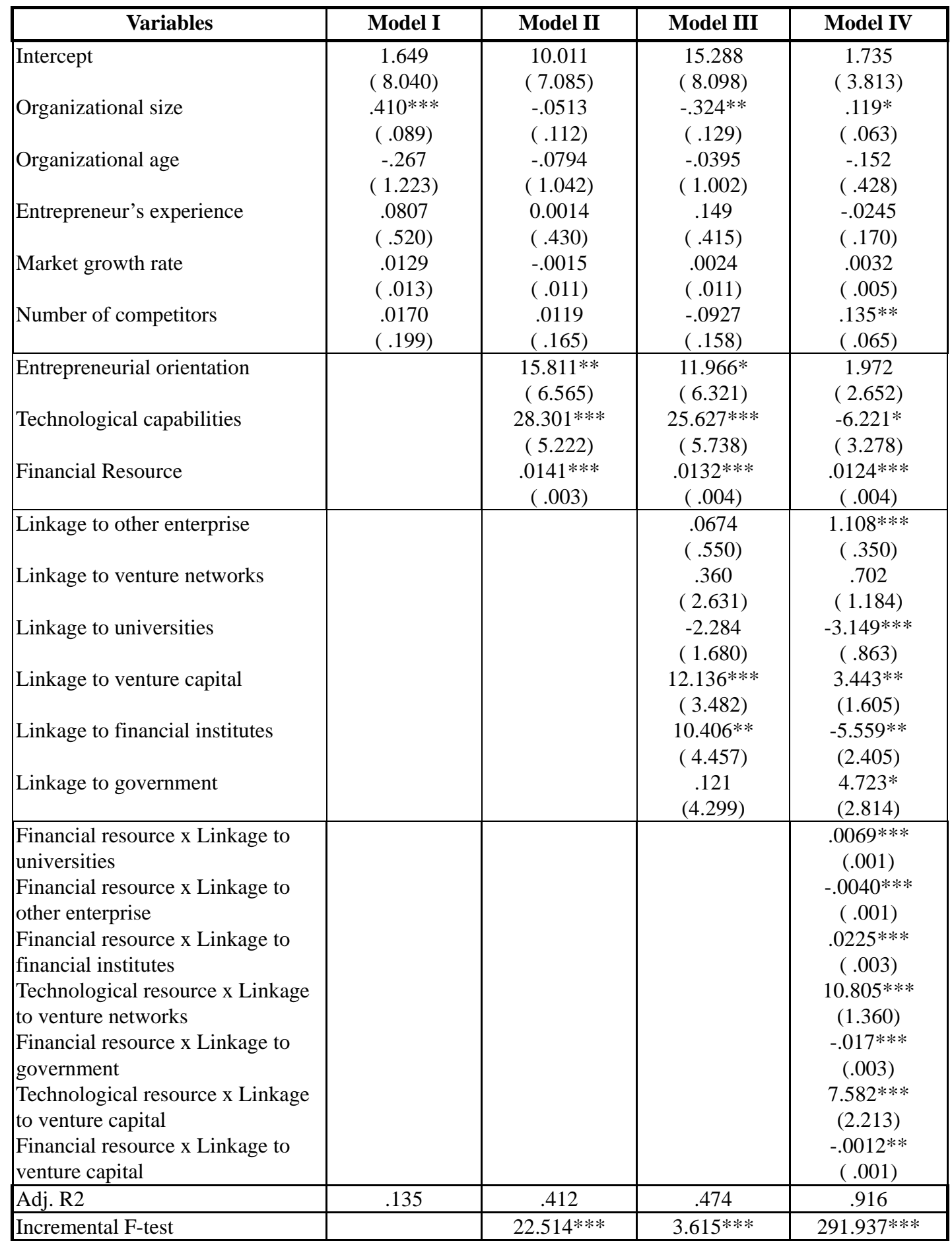

Note: Standard errors are in parentheses.

* $\mathrm{p}<.10$; ** $\mathrm{p}<.05$; *** $\mathrm{p}<.01$ 